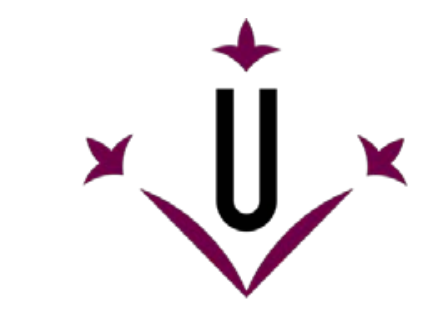

Universitat de Lleida

Document downloaded from:

http://hdl.handle.net/10459.1/60225

The final publication is available at:

https://doi.org/10.1080/01434632.2016.1177060

Copyright

(c) Taylor \& Francis, 2017 


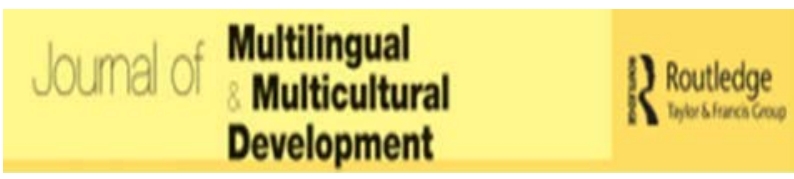

\section{Attitudinal patterns of secondary education students in Catalonia. The direct and moderator effects of origin}

\begin{tabular}{|c|c|}
\hline Journal: & J ournal of Multilingual and Multicultural Development \\
\hline Manuscript ID & J MMD- 1746.R1 \\
\hline \multirow{3}{*}{$\begin{array}{r}\text { Manuscript Type: } \\
\text { Keywords: }\end{array}$} & Paper \\
\hline & Immigrants, Language Attitudes, Multilingualism, Catalonia \\
\hline & $\begin{array}{l}\text { Language attitudes have become more relevant than ever as a result of the } \\
\text { considerable number of immigrant students enrolled in the Catalan } \\
\text { educational system and the challenges this entails in terms of promoting } \\
\text { social integration and language learning. Therefore, the objective of the } \\
\text { study is to increase our understanding of language attitudes formation by } \\
\text { analysing how origin (autochthonous or immigrant) influences (a) the } \\
\text { attitudes toward Catalan and Spanish and (b) the effects of several } \\
\text { demographic and socio-psychological variables on these attitudes. } \\
\text { Additionally, it aims to identify the most important determinants of these } \\
\text { language attitudes. For this purpose, } 1156 \text { secondary education students } \\
\text { from ten schools across Catalonia answered a language attitudes } \\
\text { questionnaire, a sociolinguistic survey, and two language competences } \\
\text { tests. The results showed that, generally, self-identifications and language } \\
\text { uses were the most influential factors. Furthermore, origin moderated the } \\
\text { relationships between attitudes and their determinants, indicating that the } \\
\text { models traditionally used to explain the attitudes held by autochthonous } \\
\text { students need to be revised to take into account the particularities of the } \\
\text { immigrant population. }\end{array}$ \\
\hline
\end{tabular}





\section{Attitudinal patterns of secondary education students in Catalonia. The direct and moderator effects of origin}

Language attitudes have become more relevant than ever as a result of the considerable number of immigrant students enrolled in the Catalan educational system and the challenges this entails in terms of promoting social integration and language learning. Therefore, the objective of the study is to increase our understanding of language attitudes formation by analysing how origin (autochthonous or immigrant) influences (a) the attitudes toward Catalan and Spanish and (b) the effects of several demographic and socio-psychological variables on these attitudes. Additionally, it aims to identify the most important determinants of these language attitudes. For this purpose, 1156 secondary education students from ten schools across Catalonia answered a language attitudes questionnaire, a sociolinguistic survey, and two language competences tests. The results showed that, generally, self-identifications and language uses were the most influential. Furthermore, origin moderated the relationships between attitudes and their determinants, indicating that the models traditionally used to explain the attitudes held by autochthonous students need to be revised to take into account the particularities of the immigrant population.

Keywords: Language attitudes, origin, immigration, multilingualism, Catalonia (Spain)

Attitudes inform and shape our experiences and reactions, as they help making sense of the world and guide decision making by providing cognitive simplicity, i.e., dividing the universe into things one likes, dislikes, or has no opinion about (Fazio 2000; Fazio and RoskosEwoldsen 2005; Heining-Boynton and Haitema 2007). Accordingly, language attitudes are a powerful force in framing and solving language related issues, which makes them especially relevant in multilingual settings, where different languages coexist and people have to negotiate 'who speaks what language to whom and when' (Fishman 1965, 67). Such is the case of Catalonia, one of Spain's bilingual autonomous communities, where both Catalan and 
Spanish have official status. Catalonia's multilingual and multicultural character has recently expanded as a result of the massive increase in immigration in the last two decades, which raised the percentage of immigrants to $14.5 \%$ of the total population (Instituto Nacional de Estadística 2015). This translates into the coexistence of more than 160 nationalities (Institut d’Estadística de Catalunya 2015) and 300 languages (Huguet 2006; Serrat, Gràcia, and Perpiña 2008) within the Catalan territory.

Thus, in order to face the social, linguistic, and educational challenges created by the migratory movements, it is essential to understand the attitudes toward Catalan and Spanish of those involved. We also have to acknowledge the differences that exist between the immigrant and the autochthonous population and consider how the particularities of each group affect the processes of attitude formation and change.

\section{Language attitudes}

Language attitudes have elicited the interest of researchers and scholars in the fields of linguistics, psychology, sociology, educational sciences, media, and political sciences because of their important role in language learning (Dewaele 2005; Dörnyei 2003; Gardner 1985; Huguet and Madariaga 2005; Masgoret and Gardner 2003; Oxford and Shearin 1994), the formation and expression of identity (Hogg and Smith 2007; Wood 2000), the design and implementation of linguistic and educational policies (Lewis 1981), and language revival and maintenance (Baker 1992; Fishman 1980).

Accordingly, the definition and operationalization of language attitudes have varied widely in terms of specificity and complexity. However, we align with Garrett (2010), who argued that 'an attitude is an evaluative orientation to a social object of some sort, whether it is a language, or a new government policy, etc.' (p. 20). In other words, a language could represent ‘an object being seen as favourable or unfavourable' (Baker 1992, 11). This 
conceptualization of attitudes toward languages is at the core of one of the main research lines in the field of language attitudes, whose emergence and development can be traced back to the seminal works of Sharp et al. (1973) and Baker (1992). The studies within this research tradition rely on the use of questionnaires to analyse attitudes toward the languages of interest.

Furthermore, considerable focus has been placed on identifying and analysing the sociodemographic and psychological determinants of language attitudes. Hence, researchers have observed a trend of attitude decline with age (e.g., Baker 1992; Bernaus, Moore, and Cordeiro Azevedo 2007; Dörnyei and Csizér 2002; Heining-Boynton and Haitema 2007; Henry and Apelgren 2008). Further, a large number of studies have found gender differences in language attitudes (e.g., Bilaniuk 2002; Dewaele 2005; Dörnyei and Csizér 2002; HeiningBoynton and Haitema 2007; Lasagabaster and Sierra 2009; Moriarty 2010; Sharp et al. 1973), although there have also been reports disproving the influence of gender (e.g., Lasagabaster 2008; Lawson and Sachdev 2004). Other variables found to influence attitudes toward languages have been socioeconomic status and sociocultural level (e.g., Bokhorst-Heng and Santos Caleon 2009; Lasagabaster 2007; Loredo Gutiérrez et al. 2007; Mettewie and Janssens 2007). At the same time, some researchers have not found any evidence of different attitudinal patterns determined by these variables (Huguet 2006; Lasagabaster 2009; Safont 2007; Ytsma 2007). However, despite the advances made in understanding the determinants of attitudes toward languages, there is still a need for more data to confirm these relationships in various social and linguistic contexts and to find out the most influential factors.

\section{Education and language attitudes in Catalonia}

Catalan and Spanish are the official languages of Catalonia, based on Catalan being Catalonia’s own language and Spanish being official throughout the Spanish State. The 
Occitan language, also known as Aranese, is spoken in Aran Valley, a northwestern county of Catalonia, and has also been granted official status since 2006, when a reformed version of the Statute of Autonomy was ratified.

Catalan has survived the one nation - one language ideology and has undergone a process of recovery, propelled by a strong institutional support consisting of a series of policies and measures of positive discrimination in favour of Catalan (e.g., introduction of language quotas in the media, requirement for bilingual service provision in the commercial sector, reinforcement of language requirements for those working in civil service, promoting the use of Catalan at all education levels) (May 2012; Woolard 2009). Among these measures, we underline the implementation of a model of bilingual education. Initially designed for children from Spanish speaking families, the early total immersion program established Catalan as the medium of instruction from the beginning of schooling in order to develop bilingualism. The bilingual education programs in Catalonia have been widely regarded as successful, as various studies showed that immersion students achieve similar or slightly higher results than non-immersion children in academic performance (Artigal 1997; Serra 1990; Vila 1995; OECD 2009). This success has been partly due to the favourable attitudes and support expressed by a considerable part of the population, regardless of their Catalan or non-Catalan background (Hoffmann 2000; Huguet 2007). Catalan has been becoming a public language, gradually de-ethnicized (Newman, Trenchs-Parera, and Ng 2008; Newman and Trenchs-Parera 2015; Pujolar and Gonzàlez 2013; Pujolar and Puigdevall 2015; Woolard 2008). In this regard, native Spanish speakers have been adopting Catalan after important life changes such as beginning primary, secondary, or university education, entering the labour market, or creating a family. Pujolar and Gonzàlez (2013) coined the term ‘mudes’ (sing. 'muda’) - roughly translated as ‘life-shifts’ (Trenchs-Parera and Newman 2015) or 'linguistic makeovers’ (Urla 2013) - to describe these changes in linguistic 
repertoires. Also, as a consequence, the roles of Catalan and Spanish speakers have become more fluid.

The traditional dichotomy between Catalan and Spanish has been further disrupted by the latest wave of international migration. Catalonia has become one of the top destinations for migrants, as the number of foreigners multiplied by ten since 2000. Currently, there are 1,025,812 foreign nationals (Instituto Nacional de Estadística 2015). Correspondingly, a total number of 163,139 immigrant children were enrolled in the Catalan system of education for the academic year 2014/2015 (Ministerio de Educación 2015). The influx of migrants has created new challenges for the Catalan educational system, which has had to adapt to the necessities and particularities of the $12.4 \%$ of the total student population that is of immigrant origin. Additionally, the maintenance of Catalan under these new circumstances has also been challenged. Strubell (2001) highlighted that the survival of the Catalan language depends on the recruitment of new speakers from the immigrant population.

The aforementioned issues were addressed by the Plan for Language and Social Cohesion ('Pla per a la Llengua i la Cohesió Social'), approved in 2004. The plan focused on the education practices directed to immigrant students, the organization of reception classrooms and the training of the teaching staff (Generalitat de Catalunya 2009). In addition, the new education context required an adaptation of the bilingual education model. As a result, the Plan for the Actualisation of the Immersion Methodology in the Current Sociolinguistic Context 2007-2013 ('Pla per a l’Actualització de la Metodologia d’Immersió en l'Actual Context Sociolingüistic 2007-2013’) was adopted. Its main objective is to achieve that, by the end of compulsory education, all students, regardless of their first language, become competent in Catalan and Spanish and can understand and deliver oral and written messages in at least one foreign language. 
As mentioned previously, the successful implementation of these policies has been strongly conditioned by the attitudes of the parties involved (Huguet 2007; Fishman 2001; Lewis 1981; Wilson 2012). Thus, researchers have investigated the attitudes of autochthonous and immigrant students, finding that the former had more favourable attitudes towards Catalan and less positive towards Spanish than their immigrant peers (Janés 2006; Madariaga, Huguet, and Lapresta 2013). Furthermore, these attitudes were determined by area of origin, home language, language competences, socioeconomic and sociocultural status (Huguet, Janés, and Chireac 2008).

Woolard (2009) interviewed 24 students from a high-school in Barcelona in order to obtain more in-depth information regarding the perception and use of Catalan and Spanish. The respondents described Catalan as elegant, refined, and formal and associated it with high professional and economic status; while Spanish was considered coarse and informal and it was associated with poor neighbourhoods and uneducated people. Echoing Pujolar's (2001) findings, students also seemed to consider Catalan less masculine. On the other hand, Bernaus and her associates (Bernaus et al. 2004; 2007) chose a questionnaire - based approach and focused on the secondary education students of a public school in Barcelona where $80 \%$ of the population came from an immigrant background. These students showed a clear preference for Spanish and English over Catalan. Additionally, they also used Spanish more frequently outside the school and rated Spanish speakers more favourably than Catalan speakers. The discrepancy between these studies might indicate underlying differences between the autochthonous population, members of which were interviewed by Woolard (2009), and the immigrant students, which predominated in the Bernaus et al.’s $(2004,2007)$ sample.

A set of 35 interviews conducted by Lapresta, Huguet, and Janés (2010) revealed different processes of language attitudes construction for autochthonous and immigrant 
students. Specifically, for autochthonous youngsters, attitude formation was strongly linked with identity, as the Catalan language was perceived as the fundamental symbol of the Catalan identity. However, the attitudes of immigrant students seemed to be strongly influenced by their personal perception of school and social integration. More precisely, the students that felt appreciated and valued in academic and social contexts tended to hold more favourable attitudes. Similar findings were reported by Newman (2011), who used focus group interviews to uncover that Latin American students perceived Catalan as an obstacle to communication and educational success, but time, proficiency, and school support seemed to lead to an improvement of their attitudes. Trenchs-Parera and Newman (2009) also found that some youngsters have begun to appreciate Catalan as a means for social progress, while Peninsular Spanish was revealed to pose an identity threat for the Latin American students, who expressed their need to maintain their language variety as a symbol of cultural distinctiveness and identity, while they also recognized the political authority, universality, and supra-ethnicity of the Spanish language. Furthermore, Corona, Nussbaum, and Unamuno (2012) observed that the Latin teenagers living in Barcelona use a Latino-Spanish repertoire, which mixes features from different parts of America and from Barcelona's language varieties, including Catalan. Several studies showed that students coming from Latin America stood out as the immigrant group with the least favourable attitudes toward Catalan and most positive attitudes toward Spanish (Janés 2006; Lapresta et al. 2009; Madariaga, Huguet, and Lapresta 2013; Newman, Trenchs-Parera, and Ng 2008).

On the other hand, non-Spanish speaking immigrant groups seem to value Catalan more than their Latin American peers. Trenchs Parera, Larrea Mendizabal, and Newman (2014) found that Chinese young people have favourable attitudes toward both Catalan and Spanish, acknowledging pragmatically that the two languages are necessary for their academic, professional, and social success. Additionally, there are reports of a highly 
favourable view of the regional language and even a symbolic identification with Catalan among Moroccan (Alarcón and Garzón 2013) and Arab and Pakistani adults (Estors Sastre 2014). Nonetheless, Fukuda (2016) observed that the Japanese people living in Catalonia share the Latin Americans' view of Catalan as irrelevant as long as Spanish is one of the official languages. However, this particular group consists of mainly temporary residents who plan to return to Japan or move to another country, an important factor in the construction of their language attitudes and their interest in the local language.

Considering the aforementioned theoretical observations and research findings, the objective of this investigation is to enhance our understanding of language attitudes and their determinants in the context of immigration in Catalonia. Furthermore, we focus on the direct and indirect influence of origin (autochthonous or immigrant) on the attitudes towards Catalan and Spanish by examining if it moderates the relationships between attitudes and the other determinants. Multivariable analyses were used to identify the most influential variables. These techniques have been used in studies investigating the attitudes toward the languages spoken in Wales (e.g., Baker 1992) and the Basque Country (e.g., Lasagabaster 2005; Moriarty 2010) but not in Catalonia.

\section{Method}

\section{Participants}

Participants were 1156 secondary education students (570 girls and 586 boys; $M_{\text {age }}=14.71$, $S D=1.29)$ from all around Catalonia (405 students from the Barcelona province, 303 from Girona, 261 from Lleida, and 187 from Tarragona). There were 666 autochthonous and 490 immigrant students. Table 1 shows the distribution of autochthonous students according to home language and the distribution of immigrant students by the linguistic family to which their home language belongs. There were 213 Spanish speakers and 277 non-Spanish 
speakers.

[INSERT TABLE 1 AROUND HERE]

\section{Materials}

Attitudes toward Catalan and Spanish were measured using a questionnaire based on the work of Sharp et al. (1973). In this sense, the aim of the questionnaire was to capture the general attitudes toward Catalan and Spanish. For this purpose, 20 dichotomous items, ten for each language, were used. The items referred to a wide range of aspects, including the subjective aesthetic properties of the language (e.g., 'Spanish is a beautiful language', 'I like listening to people speaking Catalan'), language learning (e.g., 'Learning Catalan is unpleasant', 'Learning Spanish is boring'), language practices at personal (e.g., 'I live in a place where Catalan is spoken, so I must know, study, and speak Catalan’) and general level (e.g., 'We should all try harder to use Catalan more frequently', 'In my town, we should speak less Spanish'). Positive answers received a value of +1 and unfavourable ones were codified with -1 . Thus, the final scores ranged from -10 to +10 .

The questionnaire was supplemented by a sociolinguistic survey that served to gather data concerning the sociocultural and socioeconomic status of the participants' families, the length of residence in the case of the immigrant students. Additionally, participants were asked to estimate to what degree they identify with Catalonia and with Spain, respectively, using four-point Likert scales ranging from 'not at all' to 'totally'.

Similarly, the uses of Catalan and Spanish were assessed by seven items about various contexts of language use (i.e., peers in the schoolyard, peers outside school, adults outside school, teachers, reading, watching TV, and writing).

The levels of competence in Catalan and Spanish were evaluated with the help of two parallel tests developed by Bel, Serra, and Vila (1991).The instruments focused on the written 
competences and consisted of five subtests, measuring oral and written comprehension, written expression, morphosyntax, and spelling. Scores ranged from 0 to 100, depending on the number of correct answers and errors.

All instruments have been previously successfully used in the Catalan context (Huguet, Janés, and Chireac 2008; Huguet et al. 2011; Ianos et al. 2015; Lapresta et al. 2009; Madariaga, Huguet, and Lapresta 2013; Navarro and Huguet 2006, 2010).

\section{Procedure}

The first step was to contact the Department of Education of the Government of Catalonia to obtain the necessary authorizations and to decide which schools were representative in terms of characteristics and number of immigrant students. Subsequently, ten schools from the four provinces of Catalonia were selected. The instruments were administered collectively in classrooms during school hours by a specifically trained group of people. No time limit to complete the tests was imposed. However, students took around 2 hours to answer all the questions. Participants were reminded that their answers were confidential.

\section{Statistical treatment}

The data collected was analysed using the Statistical Package for Social Sciences (SPSS v.20), which served to perform mixed - design ANOVAs and multiple linear regressions, and the computational tool PROCESS developed by Hayes (2012), which allowed us to conduct moderation analyses. The corresponding results were reported following the author's recommendations regarding the advantages of unstandardized regression coefficients over standardized ones in moderated models (Hayes 2009; Preacher and Hayes 2007). Dummy coding was used to introduce the categorical variables in the multiple regression analyses. Furthermore, effect sizes were calculated for focused effects (Field 2013; Kline 2004). We also used the robust bootstrap method to obtain parameters that do not rely on assumptions of 
normality or homoscedasticity samples (Field 2013; Efron and Tibshirani 1993). Bias

corrected and accelerated (BCa) confidence intervals (CI) were based on 2000 bootstrap samples.

\section{Results}

Following, the results are presented according to a three-part structure: the direct influence of origin, the moderating influence of origin on the effects of each variable individually, and the multiple regression models that indicate the most influential determinants.

\section{The effect of origin on attitudes toward Catalan and Spanish}

First, a 2x2 mixed-design ANOVA with origin (autochthonous, immigrant) as the betweensubjects factor and attitudes toward language (Catalan, Spanish) as the within-subjects variable was performed to examine the attitudinal patterns determined by origin. The results showed that autochthonous students had more favourable attitudes toward Catalan than Spanish $\left(t_{(1154)}=7.30, p<.001, r=.21\right)$. However, the contrary was observed in the case of immigrant students, who preferred Spanish to Catalan $\left(t_{(1154)}=-5.83, p<.001, r=-.17\right)$. Table 1 presents the corresponding means and standard deviations.

[INSERT TABLE 2 AROUND HERE]

\section{The moderated effects of sociodemographic and psychological variables on attitudes toward Catalan and Spanish}

Second, in order to explore the moderation effect of origin on the relationships between the categorical variables of interest and attitudes, origin was introduced as a between-subjects factor in a series of mixed-design ANOVAs.

A 2x2x2 mixed-design ANOVA was used to examine the influence of gender on the attitudes toward Catalan and Spanish. The results showed that origin did not moderate the 
effect of gender on the attitudes toward the two official languages of Catalonia. Nonetheless, a main effect of gender was found $\left(F_{(1,1152)}=23.66, p<.001, r=.14\right)$, according to which girls had more favourable attitudes toward both Catalan and Spanish, regardless of origin.

Furthermore, a 2x2x2 ANOVA with socioeconomic status (low, medium-high) and origin as the between-subjects factors and attitudes toward language as the within-subjects variable revealed that origin moderated the attitudinal patterns determined by socioeconomic status. Thus, autochthonous students from families of medium-high status had more favourable attitudes toward Catalan $(t=2.53, p=.013, r=.07)$ and less positive attitudes toward Spanish $(t=-5.74, p<.001, r=-.17)$ than their peers from a low status background. Meanwhile, the attitudes toward Catalan $(t=-1.36, p=.177, r=.04)$ and Spanish $(t=-0.19$, $p=.850, r=.01$ ) held by immigrant students did not vary by socioeconomic status.

A similar analysis revealed a significant interaction effect between sociocultural level, origin, and attitudes toward languages. Specifically, autochthonous students whose parents graduated university studies expressed more favourable attitudes toward Catalan $\left(t_{(1154)}=\right.$ 3.46, $p=.001, r=.10$ ) and less positive toward Spanish than the children whose parents finished secondary or primary education ( $t=-5.73, p<.001, r=-.17)$. Sociocultural status did not determine significant differences in the attitudes toward Catalan $(t=-0.44, p=.656, r$ $=-.01)$ and Spanish $\left(t_{(1154)}=-1.26, p=.209, r=-.04\right)$ of immigrant students.

The computational tool PROCESS, developed by Hayes (2012) was used to conduct moderation analyses to investigate whether the effects of the continuous variables on attitudes varied by origin. Accordingly, when analysing the relationship between written competences in Catalan and attitudes toward Catalan, the interaction term contributed significantly to the explained variance $\left(F_{(1,1152)}=22.22, p<.001\right)$, indicating a moderating effect of origin. This interaction was broken down by estimating the simple slopes, which indicated a slightly stronger effect for the autochthonous $(b=0.1,95 \%$ BCa CI [0.08, 0.13], SE $b=0.01, p<$ 
$.001)$ than for the immigrant group of students $(b=0.03$, 95\% BCa CI [0.01, 0.04], SE $b=$ $0.01, p=.010)$. Further, the relationship between the degree of competence in Catalan and attitudes toward Spanish depended on origin $\left(F_{(1,1152)}=40.45, p<.001\right)$. Specifically, Catalan competences positively influenced the attitudes toward Spanish held by the immigrant group ( $b=0.03$, 95\% BCa CI [0.01, 0.05], SE $b=0.01, p=.009$ ), while in the case of the autochthonous group higher Catalan competences were associated with less favourable attitudes toward Spanish $(b=-0.08,95 \%$ BCa CI [-0.11, -0.06$]$, SE $b=0.01, p<$ $.001)$.

Origin was also found to moderate the relationship between written competences in Spanish and attitudes toward Catalan $\left(F_{(1,1152)}=8.28, p=.004\right)$. Thus, the autochthonous students’ degree of competence in Spanish was positively related to their attitudes toward Catalan $(b=0.04,95 \%$ BCa CI [0.01, 0.07], SE $b=0.01, p=.010)$, while, in the case of the immigrant participants, the two variables were not significantly associated $(b=-0.01,95 \%$ BCa CI [-0.03, 0.01], SE $b=0.01, p=.185)$. However, the effect of competence in Spanish on attitudes toward Spanish was too small to reach significant levels $(b=0.00,95 \%$ BCa CI $[-0.01,0.01], S E b=0.01, p=.990)$, regardless of the participants' origin $\left(F_{(1,1152)}=3.00, p=\right.$ $.083)$.

Furthermore, self-identification with Catalonia had a more powerful effect on attitudes toward Catalan for autochthonous students $(b=3.04,95 \%$ BCa CI [3.32, 2.76], SE $b$ $=0.14, p<.001)$ than for their immigrant peers $(b=1.86,95 \%$ BCa CI $[1.54,2.17], S E b=$ $0.16, p<.001)\left(F_{(1,1152)}=30.73, p<.001\right)$. Although negative, the relationship between selfidentification with Catalonia and attitudes toward Spanish followed a similar pattern $\left(F_{(1,1152)}\right.$ $=78.11, p<.001)$, being stronger when the participants were autochthonous $(b=-2.49,95 \%$ BCa CI [-2.81, -2.18], SE $b=0.16, p<.001)$ than when they were of immigrant origin $(b=$ $0.40,95 \%$ BCa CI [-0.74, -0.05], SE $b=0.18, p=.024)$. The effect of self-identification with 
Spain on attitudes toward Catalan was also moderated by origin $\left(F_{(1,1152)}=140.76, p<.001\right)$. Thus, the attitudes toward Catalan of autochthonous participants were more positive the less they identified with Spain $(b=-1.99,95 \%$ BCa CI [-2.26, -1.71], SE $b=0.14, p<.001)$, while immigrants with high self-identifications with Spain tended to express favourable attitudes toward Catalan ( $b=0.64,95 \%$ BCa CI [0.31, 0.98], SE $b=0.17, p<.001)$. Additionally, self-identification with Spain had a positive effect on attitudes toward Spanish for autochthonous students ( $b=3.22,95 \%$ BCa CI [2.99, 3.46], SE $b=0.12, p<.001$ ), but no significant effect when considering the immigrant group ( $b=0.18$, 95\% BCa CI [-0.47, 0.10], $S E b=0.15, p=.210)\left(F_{(1,1152)}=262.38, p<.001\right)$.

Use of Catalan was found to positively influence the attitudes toward Catalan held by both autochthonous ( $b=3.38,95 \%$ BCa CI [3.06, 3.71], SE $b=0.16, p<.001)$ and immigrant students $(b=2.34$ [1.96, 2.72], $S E b=0.19, p<.001)$, although the effect was stronger for the former $\left(F_{(1,1152)}=17.16, p<.001\right)$. On the other hand, use of Catalan had a negative effect on attitudes toward Spanish, which also varied by origin $\left(F_{(1,1152)}=77.48, p<\right.$ $.001)$, being stronger for the autochthonous participants $(b=-2.97,95 \%$ BCa CI [-3.31, 2.62], SE $b=0.18, p<.001)$ than for those of immigrant origin $(b=-0.59$, 95\% BCa CI [0.99, -0.19], $S E b=0.20, p=.004)$. In a similar manner, use of Spanish had a more powerful positive influence on attitudes toward Spanish in the case of the autochthonous group $(b=$ 3.81, 95\% BCa CI [3.51, 4.11], SE $b=0.15, p<.001)$ than for the immigrant one $(b=1.50$, 95\% BCa CI [1.09, 1.91], SE $b=0.21, p<.001)\left(F_{(1,1152)}=80.22, p<.001\right)$. However, the negative relationship between use of Spanish and attitudes toward Catalan $(b=-2.21,95 \%$ BCa CI [-2.45, -1.95], SE $b=0.13, p<.001)$ did not vary by origin $\left(F_{(1,1152)}=2.02, p=\right.$ $.156)$.

A series of immigrant - specific variables were also investigated with the help of simple linear regressions. Consequently, length of residence was found to be positively 
related to attitudes toward Catalan $(b=0.10,95 \%$ BCa CI [0.03, 0.22], $S E b=0.05, p=$ .007), explaining $2 \%$ of their variance, while the relationship with attitudes toward Spanish was not statistically significant $\left(R^{2}=.00, b=-0.01,95 \%\right.$ BCa CI [-0.08, 0.05], SE $b=0.03, p$ $=.686)$.

The differences between Spanish and non-Spanish speaking immigrant students were also considered. The results of a 2x2 mixed-design ANOVA showed an interaction effect the variables analyzed $\left(F_{(1,488)}=46.84, p<.001\right)$. Specifically, Spanish speakers had more positive attitudes toward Spanish $\left(t_{(1154)}=5.43, p<.001, r=.24\right)$ and less favourable attitudes toward Catalan $\left(t_{(1154)}=-4.67, p<.001, r=-.21\right)$ than the non-Spanish speakers.

\section{Multiple regression models of the factors thought to influence attitudes toward}

\section{Catalan and Spanish}

Lastly, after seeing how each variable influenced the attitudes toward Catalan and Spanish depending on the origin of participants, multiple linear regression analyses were carried out to assess which factors best explain students' attitudes in the particular context of Catalonia.

The results of the simultaneous multiple regressions carried out for the autochthonous group are summarized in Table 4. Thus, the model proposed for attitudes toward Catalan, which included gender, socioeconomic status, sociocultural level, written competences in Catalan and Spanish, self-identification with Catalonia and Spain, and use of Catalan and Spain, explained 58\% of the variance. The most influential variables were, in order, selfidentification with Catalonia, use of Catalan, self-identification with Spain, use of Spanish, socioeconomic status, and gender. Regarding the attitudes toward Spanish held by autochthonous students, the model explained $57 \%$ of the variance. The factors found to be significant predictors were self-identification with Spain, use of Spanish, and use of Catalan.

\section{[INSERT TABLE 3 AROUND HERE]}


Furthermore, hierarchical multiple regression analyses were performed to investigate which variables were the most influential when it came to the attitudes of immigrant students. The variables previously considered for the autochthonous group were introduced in the first step, while the immigrant specific variables (i.e., Spanish/ non-Spanish speaking and length of residence) were introduced in the second step to observe changes in explanatory power. The results, which are summarized in Table 5, revealed that the model accounted for $26 \%$ of the variance in attitudes toward Catalan. The significant determinants were, in order, use of Catalan, self-identification with Catalonia, use of Spanish, gender, and sociocultural level. Adding the immigrant specific variables did not change the amount of variance explained, but it removed sociocultural level from the list of significant predictors.

In the case of attitudes toward Spanish, the model explained $17 \%$ of the variance. The significant determinants of the immigrant students' attitudes toward Spanish were use of Spanish, self-identification with Spain, and degree of competence in Catalan. Including the immigrant specific variables increased the amount of variance explained to $18 \%$, as being Spanish or non-Spanish speaker was revealed to be a significant factor.

\section{[INSERT TABLE 4 AROUND HERE]}

\section{Discussion and conclusions}

The study examined the influence of origin as a moderator variable on processes of attitude formation and change, focusing on the attitudes toward Catalan and Spanish held by secondary education students. First of all, our findings add empirical data to confirm that autochthonous and immigrant students have different attitudinal patterns, as the former tend to favour Catalan and the latter Spanish (Janés 2006; Lapresta et al. 2009; Lapresta, Huguet, and Janés 2010; Madariaga, Huguet, and Lapresta 2013; Trenchs-Parera and Newman 2009; Bernaus et al. 2004). 
Furthermore, we uncovered new relevant information by finding support for the moderator role of origin in the relationships between the attitudes toward Catalan and Spanish and most of their determinants. The only variable whose effect was not moderated by origin was gender. As it has been frequently observed (e.g., Bilaniuk 2002; Dewaele 2005; Dörnyei and Csizér 2002; Heining-Boynton and Haitema 2007; Henry and Apelgren 2008; Lasagabaster and Sierra 2009; Loredo Gutiérrez et al. 2007; Moriarty 2010; Sharp et al. 1973), girls tend to have more positive attitudes toward languages than boys. Dewaele (2005) interpreted these findings as a result of socialization which emphasizes girls' socio-emotional orientations. It is also possible that boys' and girls' attitudes, motivations, and behaviours tend to follow gender role stereotypes, with boys reporting more interest in mathematics and science and girls in language, arts, and writing (Meece, Glienke, and Burg 2006). The gendered attitudes toward Catalan could also reflect the perception of the local language as less masculine (Pujolar 2001; Woolard 2009) or as lacking vulgar registers (Newman, PatiñoSantos, and Trenchs-Parera 2012).

On the other hand, origin affected the strength of the effects of socioeconomic status, sociocultural level, degree of written competences in Catalan and Spanish, self-identification with Catalonia and Spain, and use of Catalan on attitudes toward Catalan, as well as the effects of socioeconomic status, sociocultural level, self-identification with Catalonia and Spain, and use of Spanish on attitudes toward Spanish. Origin also changed the direction of the relationships between competences in Catalan and attitudes toward Spanish and between self-identification with Spain and attitudes toward Catalan. These results indicate that the processes of attitude construction and change differ between autochthonous and immigrant students, corroborating Newman et al.'s (2012) observation that 'the trajectory of language attitudes of the descendants of the prior immigration process may not make an appropriate model for current immigrants’' (p. 201). 
Moreover, the sociodemographic affective variables analysed had stronger effects on the attitudes toward Catalan and Spanish of autochthonous participants than on the language attitudes of immigrants. The amount of variance of attitudes toward Catalan and Spanish explained by the same set of variables for the former group was approximately double than in the case of the immigrant group. Therefore, the variables traditionally investigated are probably not the most adequate when it comes to the new population of students of immigrant origin. For instance, socioeconomic status and sociocultural level influenced the attitudes of autochthonous students, but were not relevant for immigrants. Autochthonous participants from families with higher socioeconomic status and sociocultural level expressed more favourable attitudes toward Catalan and less positive ones toward Spanish. These results are not surprising considering that Catalan maintained its high status during the Franco dictatorship and has later become the institutional and education language, strongly associated with political and economical power, a position further strengthened by the internal migration of the 1970s, when Spanish speaking families from the poorer regions of the country moved to Catalonia and concentrated mostly in the working class (Frekko 2009; Woolard 1991). The relationship between socioeconomic status and language attitudes inferred from our sample of secondary education students aligns with Pujolar and Gonzàlez's (2013) findings that status is associated with interest in formal and higher education and Soler's (2012) data about the prevalence of instrumental reasons to learn and use Catalan as a means for upward social mobility. Frekko’s (2012) further argues that the economic and cultural background plays a more important role in acquiring certification in Catalan than the home language.

Furthermore, when looking at the patterns in the data suggested by the multiple regression analyses, self-identifications and language uses were revealed to be the most important factors of attitudes toward Catalan and Spanish for both groups of origin. These 
findings align with those of Lapresta and collaborators (2010; 2009), who also noted that the attitudes of autochthonous youngsters were anchored in their identity. The powerful link between attitudes and identity is not surprising, considering the strong theoretical substantiation it has received. Thus, Hogg and Smith (2007) argued that "attitudes are windows on identity” (p. 89), because they serve to define and express one's identity, as well as to infer the identities of other individuals. Attitudes are also associated to group membership, seeing that individual attitudes reflect group normative attitudes that articulate intergroup similarities and differences between the in-group and the out-group (Wood 2000). In this sense, even though it has become a more public language (Newman, Trenchs-Parera, and Ng 2008; Newman and Trenchs-Parera 2015; Woolard 2008), Catalan remains the main symbol of the Catalan culture and identity. Similarly, language use represents a marker of group identity and is one of the main ways of defining and expressing one's attitudes and identification. In addition, Pujolar and Gonzàlez (2013) showed that people change their language uses as consequence of various important life changes, such as graduations, meeting new friends, teachers, joining new institutions. The most frequent muda the authors identified was the adoption of Catalan by Spanish speakers attending Catalan-medium schools. Subsequently, frequent use of a language usually leads to an improvement in attitudes (Csizér and Kormos 2008). Therefore, favourable language attitudes could be promoted by encouraging contact between speakers of different languages and creating opportunities for language use.

Although we focused on the influence of self-identifications and language use on attitudes toward languages, all these variables are most likely interrelated, reciprocally built constructs that strengthen each other. As Brown and Sachdev (2009) explained, this pattern of dynamic and interdependent relationships between attitudes, self-identifications, and language use also has a reciprocal relationship with the social patterns of bilingualism. Thus, 
the negative relationships between the Catalan-related variables and those concerning Spanish seem to reflect the historically competitive relationship between Catalan and Spanish. Specifically, an increase in use of Catalan was associated with a higher selfidentification with Catalonia and an improvement of attitudes toward Catalan, but a decline in use of Spanish, a lower self-identification with Spain and less favourable attitudes toward Spanish. The pattern suggests the predominance of parochial ideologies and, thus, contradicts previous studies indicating the proliferation of cosmopolitan ideologies among young people in Barcelona (Newman, Trenchs-Parera, and Ng 2008; Trenchs-Parera and Newman 2009; Trenchs-Parera, Larrea Mendizabal, and Newman 2014; Woolard 2012). However, there are also reports of adolescents taking mutually exclusive stances in favour of one of the two opposing languages (Newman 2011; Trenchs-Parera and Newman 2009) and rejecting language mixing (Woolard 2009). The nucleus of ideological change toward cosmopolitanism seems to be located in the Barcelona metropolitan area, from where it might be spreading at irregular rates across the rest of the Catalan territory. As the results of the present study suggest, when considering all four provinces of Catalonia, the ethnolinguistic division between Catalan and Spanish still determines youngsters’ language attitudes and uses.

Concerning the immigrant participants, the explanatory models need improvement. Of the immigrant-specific variables considered, only being a Spanish speaker contributed significantly to the explained variance of attitudes toward Spanish, which not only confirms previous studies (Huguet, Janés, and Chireac 2008; Madariaga, Huguet, and Lapresta 2013; Janés 2006; Lapresta et al. 2009; Newman, Trenchs-Parera, and Ng 2008), but also underlines the heterogeneity of the immigrant population. Various immigrant groups from Latin American (Newman, Patiño-Santos, and Trenchs-Parera 2012), Morocco (Alarcón and Garzón 2013), China (Trenchs-Parera 2013), Japan (Fukuda 2016), Arab and Pakistan (Estors 
Sastre 2014) have been investigated in order to understand their particularities and how these relate to their language behaviours and attitudes. However, more systematic studies are needed to identify the most important determinants of immigrants’ attitudes. Such a factor could be the personal perception of academic and social integration and appreciation (Lapresta et al. 2009) or school adaptation (Siqués, Perera, and Vila 2012). The implementation of the Community Plan as a part of the Plan for Language and Social Cohesion (2004) designed to involve the community in the creation of a support network outside school seems to be a first step in this direction. However, more actions are needed to encourage contact between communities and to facilitate immigrants’ social integration.

To conclude, the present study brought new evidence regarding the direct and moderator effect of origin on attitudinal patterns and processes of construction in the case of secondary education students in Catalonia. Consequently, it emphasized the importance of considering the particularities of each group when designing and implementing social, linguistic, and educational measures and policies. The study also reached its objective of identifying the most influential determinants of attitudes toward Catalan and Spanish by uncovering the critical role played by self-identifications and language use.

\section{ACKNOWLEDGEMENTS}

This work was supported by the Ministry of Economy and Competitiveness of the Government of Spain [grant number EDU2014-54093-R] and Government of Catalonia - Agència de Gestió d’ajuts Universitaris i de Recerca (AGAUR) [grant number 2014 SGR 208]. 


\section{References}

Alarcón, Amado, and Luis Garzón. 2013. “Children of Immigrants and Social Mobility in Officially Bilingual Societies The Case of Catalonia.” Spanish in Context 10 (1): 92113. doi:10.1075/sic.10.1.04ala.

Artigal, Josep Maria. 1997. “The Catalan Immersion Program.” In Immersion Education: International Perspectives, edited by R.K. Johnson and M. Swain, 133-50. Cambridge, UK: Cambridge University Press.

Baker, Colin. 1992. Attitudes and Language. Clevedon: Multilingual Matters.

Bel, Aurora, Josep Maria Serra, and Ignasi Vila. 1991. El Coneixement de Llengua Catalana $a$ Gè, 7è I 8è d'EGB. Barcelona: ICE Universitat de Barcelona.

Bernaus, Mercè, Anne-Marie Masgoret, Robert C. Gardner, and Edith Reyes. 2004. "Motivation and Attitudes towards Learning Languages in Multicultural Classrooms.” International Journal of Multilingualism 1 (2): 75-89. doi:10.1080/14790710408668180.

Bernaus, Mercè, Emilee Moore, and Adriana Cordeiro Azevedo. 2007. “Affective Factors Influencing Plurilingual Students’ Acquisition of Catalan in a Catalan-Spanish Bilingual Context.” The Modern Language Journal 91 (2): 235-46. doi:10.1111/j.1540-4781.2007.00542.x.

Bilaniuk, Laada. 2002. “Gender, Language Attitudes, and Language Status in Ukraine.” Language in Society 32 (01): 47-78. doi:10.1017/S0047404503321037.

Bokhorst-Heng, Wendy D., and Imelda Santos Caleon. 2009. “The Language Attitudes of Bilingual Youth in Multilingual Singapore.” Journal of Multilingual and Multicultural Development 30 (3): 235-51. doi:10.1080/01434630802510121.

Brown, Ivan, and Itesh Sachdev. 2009. "Bilingual Behaviour, Attitudes, Identity and Vitality: Some Data from Japanese Speakers in London, UK.” Journal of Multilingual and Multicultural Development 30 (4): 327-43. doi:10.1080/01434630902780715.

Corona, Víctor, Luci Nussbaum, and Virginia Unamuno. 2012. “The Emergence of New Linguistic Repertoires among Barcelona’s Youth of Latin American Origin.” International Journal of Bilingual Education and Bilingualism 16 (2): 1-13. doi:10.1080/13670050.2012.720668. 
Csizér, Kata, and Judit Kormos. 2008. "Modelling the Role of Inter-Cultural Contact in the Motivation of Learning English as a Foreign Language.” Applied Linguistics 30 (2): 166-85. doi:10.1093/applin/amn025.

Dewaele, Jean-Marc. 2005. “Sociodemographic, Psychological and Politicocultural Correlates in Flemish Students’ Attitudes towards French and English.” Journal of Multilingual and Multicultural Development 26: 118-37.

Dörnyei, Zoltán. 2003. “Attitudes, Orientations, and Motivations in Language Learning: Advances in Theory, Research, and Applications.” Language Learning 53 (S1): 3-32. doi:10.1111/1467-9922.53222.

Dörnyei, Zoltán, and Kata Csizér. 2002. “Some Dynamics of Language Attitudes and Motivation: Results of a Longitudinal Nationwide Survey.” Applied Linguistics 23 (4): 421-62. doi:10.1093/applin/23.4.421.

Efron, Bradley, and Robert Tibshirani. 1993. An Introduction to the Bootstrap. Boca Raton, FL: Chapman \& Hall.

Estors Sastre, Laura. 2014. “Les Actituds Lingüístiques segons l’Origen dels Aprenents de Català com a Llengua d’Acollida.” Treballs de Sociolingüística Catalana 24: 153-71. doi:10.2436/20.2504.01.74.

Fazio, Russell H. 2000. “Accessible Attitudes as Tools for Object Appraisal: Their Costs and Benefits.” In Why We Evaluate: Functions of Attitudes, edited by Gregory R. Maio and J. M. Olson, 1-36. Mahwah, NJ: Lawrence Erlbaum Associates.

Fazio, Russell H., and David Roskos-Ewoldsen. 2005. “Acting as We Feel: When and How Attitudes Guide Behavior.” In Persuasion: Psychological Insights and Perspectives, edited by Timothy Brock and Melanie Green, 2nd ed., 41-62. Thousand Oaks, CA: Sage Publications, Inc.

Field, Andy. 2013. Discovering Statistics Using IBM SPSS Statistics. 4th ed. London: Sage Publications.

Fishman, Joshua A. 1965. “Who Speaks What Language to Whom and When?” La Linguistique 1 (2): 67-88.

— 1980. "Minority Language Maintenance and the Ethnic Mother Tongue School.” The Modern Language Journal 64 (2): 167-72.

- 2001. Can Threatened Languages Be Saved? Reversing Language Shift, Revisited: A 21st Century Perspective. Multilingual Matters.

Frekko, Susan E. 2009. "Social Class, Linguistic Normativity and the Authority of the ‘Native Catalan Speaker’ in Barcelona.” In The Native Speaker Concept: 
Ethnographic Investigations of Native Speaker Effects, 161-84. Berlin: Mouton de Gruyter.

— 2012. "Legitimacy and Social Class in Catalan Language Education for Adults.” International Journal of Bilingual Education and Bilingualism 16 (2): 129-137. doi:10.1080/13670050.2012.720666.

Fukuda, Makiko. 2016. "Double Gateway to the Host Society? Knowledge and Perceptions of Japanese People Living in Catalonia Regarding Language.” Journal of Multilingual and Multicultural Development. doi:10.1080/01434632.2016.1146288.

Gardner, Robert C. 1985. Social Psychology and Second Language Learning: The Role of Attitudes and Motivation. London: Edward Arnold.

Garrett, Peter. 2010. Attitudes to Language. Cambridge: Cambridge University Press.

Generalitat de Catalunya. 2009. “Pla per a La Llengua I La Cohesió Social. Educació I Convivència Intercultural.” http://www.xtec.cat/alfresco/d/d/workspace/SpacesStore/2d96e1d3-81fc-4de9-9fec508acde1dcbe/Annex1_aules_nov_09.pdf.

Hayes, Andrew F. 2009. "Beyond Baron and Kenny: Statistical Mediation Analysis in the New Millenium.” Communication Monographs 76 (4): 408-20. doi:10.1080/03637750903310360.

—_. 2012. "PROCESS: A Versatile Computational Tool for Observed Variable Mediation, Moderation and Conditional Process Modeling.” White Paper. Retrieved from http://www.afhayes.com/public/process2012.pdf, 1-39.

Heining-Boynton, Audrey L., and Thomas Haitema. 2007. “A Ten-Year Chronicle of Student Attitudes toward Foreign Language in the Elementary School.” The Modern Language Journal 91 (2): 149-68. doi:10.1111/j.1540-4781.2007.00538.x.

Henry, Alastair, and Britt Marie Apelgren. 2008. "Young Learners and Multilingualism: A Study of Learner Attitudes before and after the Introduction of a Second Foreign Language to the Curriculum.” System 36 (4). Elsevier Ltd: 607-23. doi:10.1016/j.system.2008.03.004.

Hoffmann, Charlotte. 2000. "Balancing Language Planning and Language Rights: Catalonia’s Uneasy Juggling Act.” Journal of Multilingual and Multicultural Development 21 (5): 425-41.

Hogg, Michael A., and Joanne R. Smith. 2007. “Attitudes in Social Context: A Social Identity Perspective.” European Review of Social Psychology 18 (1): 89-131. doi:10.1080/10463280701592070. 
Huguet, Àngel. 2006. “Attitudes and Motivation versus Language Achievement in CrossLinguistic Settings. What Is Cause and What Effect?” Journal of Multilingual and Multicultural Development 27 (5): 413-29. doi:10.2167/jmmd426.1.

_. 2007. "Minority Languages and Curriculum: The Case of Spain.” Language, Culture and Curriculum 20 (1): 70-86. doi:10.2167/lcc327.0.

Huguet, Àngel, Silvia Maria Chireac, José Luis Navarro, and Clara Sansó. 2011. “Tiempo de Estancia y Aprendizajes Lingüísticos. El Caso de los Escolares Inmigrantes en Cataluña.” Cultura y Educación 23 (3): 355-70.

Huguet, Àngel, Judit Janés, and Silvia Maria Chireac. 2008. “Mother Tongue as a

Determining Variable in Language Attitudes. The Case of Immigrant Latin American Students in Spain.” Language and Intercultural Communication 8 (4): 246-60. doi:10.1080/14708470802303082.

Huguet, Àngel, and José M. Madariaga. 2005. Fundamentos de Educación Bilingüe. Bilbao: Universidad del País Vasco.

Ianos, Maria-Adelina, Àngel Huguet, Judit Janés, and Cecilio Lapresta. 2015. “Can Language Attitudes Be Improved? A Longitudinal Study of Immigrant Students in Catalonia (Spain).” International Journal of Bilingual Education and Bilingualism, August. 115. doi:10.1080/13670050.2015.1051508.

Institut d’Estadística de Catalunya (Idescat). 2015. Població Estrangera. http://www.idescat.cat/poblacioestrangera/.

Instituto Nacional de Estadística. 2015. Continous Register Statistics. http://www.ine.es/jaxi/menu.do?type=pcaxis\&path=/t20/e245/\&file=inebase.

Janés, Judit. 2006. “Las Actitudes hacia las Lenguas y el Aprendizaje Lingüístico.” Revista Interuniversitara de Formación Del Profesorado 20 (2): 117-32.

Kline, Rex B. 2004. Beyond Significance Testing: Reforming Data Analysis Methods in Behavioral Research. Washington, DC: American Psychological Association. Lapresta, Cecilio, Silvia Maria Chireac, Àngel Huguet, José Luis Navarro, Monica Querol, and Clara Sansó. 2009. Actitudes Lingüísticas, Escuela e Inmigración. Los Escolares ante la Diversidad Lingüística y Cultural. Madrid: Ministerio de Educación, Subdirección General de Información y Publicaciones.

Lapresta, Cecilio, Àngel Huguet, and Judit Janés. 2010. “Análisis Discursivo de las Actitudes Lingüísticas de los Escolares de Origen Inmigrante en Cataluna.” Revista de Educación 353: 521-47. 
Lasagabaster, David. 2005. “Attitudes towards Basque, Spanish and English: An Analysis of the Most Influential Variables.” Journal of Multilingual and Multicultural Development 26 (4). Routledge. 2007. “Language Use and Language Attitudes in the Basque Country.” In Multilingualism in European Bilingual Contexts. Language Use and Attitudes, edited by David Lasagabaster and Ángel Huguet, 65-89. Clevedon, UK: Multilingual Matters.

—. 2008. "Basque Diaspora in the USA and Language Maintenance.” Journal of Multilingual and Multicultural Development 29 (1): 66-90. doi:10.2167/jmmd567.0. —. 2009. "Multilinguismo y Actitudes Linguisticas: El Papel Democratizador de la Escuela.” Voces Hispanas 6: 12-18.

Lasagabaster, David, and Juan Manuel Sierra. 2009. "Language Attitudes in CLIL and Traditional EFL Classes.” International CLIL Research Journal 2 (1): 4-17. Lawson, Sarah, and Itesh Sachdev. 2004. "Identity, Language Use, and Attitudes: Some Sylheti-Bangladeshi Data from London, UK.” Journal of Language and Social Psychology 23 (1): 49-69. doi:10.1177/0261927X03261223.

Lewis, E. Glyn. 1981. Bilingualism and Bilingual Education. Oxford, UK: Pergamon. Loredo Gutiérrez, Xaquin, Antonio Fernández Salgado, Isabel Suárez Fernández, and Hakan Casares Berg. 2007. “Language Use and Language Attitudes in Galicia.” In Multilingualism in European Bilingual Contexts. Language Use and Attitudes, edited by David Lasagabaster and Ángel Huguet, 40-64. Clevedon, UK: Multilingual Matters.

Madariaga, José M., Àngel Huguet, and Cecilio Lapresta. 2013. “Attitudes, Social Pressure and Inclusive Education in Classrooms with Cultural and Linguistic Diversity.” Educación XXI 16 (1): 305-28. doi:10.5944/educXX1.16.1.728.

Masgoret, Anne-Marie, and Robert C. Gardner. 2003. “Attitudes, Motivation, and Second Language Learning: A Meta-Analysis of Studies Conducted by Gardner and Associates.” Language Learning 53 (1): 167-210. doi:10.1111/1467-9922.00227.

May, Stephen. 2012. Language and Minority Rights: Ethnicity, Nationalism and the Politics of Language. 2nd ed. New York, NY: Routledge.

Meece, J.L., B. Glienke, and S. Burg. 2006. “Gender and Motivation.” Journal of School Psychology 44 (5): 351-73.

Mettewie, Laurence, and Rudi Janssens. 2007. “Language Use and Language Attitudes in Brussels.” In Multilingualism in European Bilingual Contexts. Language Use and 
Attitudes, edited by David Lasagabaster and Ángel Huguet, 117-43. Clevedon, UK: Multilingual Matters.

Ministerio de Educación, Cultura y Deporte. 2015. Enseñanzas No Universitarias. Alumnado Matriculado. http://www.mecd.gob.es/servicios-al-ciudadanomecd/estadisticas/educacion/no-universitaria/alumnado/matriculado/series.html. Moriarty, Máiréad. 2010. “The Effects of Language Planning Initiatives on the Language Attitudes and Language Practices of University Students A Comparative Study of Irish and Basque.” Language Problems \& Language Planning 34 (2): 141-57. doi:10.1075/lplp.34.2.03mor.

Navarro, José Luis, and Àngel Huguet. 2006. “Creencias y Conocimiento acerca de la Competencia Lingüística de Alumnado Inmigrante. El Caso de La Provincia de Huesca.” Revista de Investigación Educativa 24 (2): 373-94.

— 2010. "The Knowledge of Catalan and Spanish in Migrant Students.” Revista de Educación 352: 245-65.

Newman, Michael. 2011. "Different Ways to Hate a Language in Catalonia: Interpreting Low Solidarity Scores in Language Attitude Studies.” In Selected Proceedings of the 5th Workshop on Spanish Sociolinguistics, edited by Jim Michnowicz and Robin Dodsworth, 40-49. Somerville, MA: Cascadilla Proceedings Project.

Newman, Michael, Adriana Patiño-Santos, and Mireia Trenchs-Parera. 2012. "Linguistic Reception of Latin American Students in Catalonia and Their Responses to Educational Language Policies.” International Journal of Bilingual Education and Bilingualism 0050 (February 2015): 1-15. doi:10.1080/13670050.2012.720669.

Newman, Michael, and Mireia Trenchs-Parera. 2015. "Language Policies, Ideologies and Attitudes in Catalonia. Part 1: Reversing Language Shift in the Twentieth Century.” Language and Linguistics Compass 9 (7): 285-94. doi:10.1111/lnc3.12141.

Newman, Michael, Mireia Trenchs-Parera, and Shukhan Ng. 2008. “Normalizing bilingualism: The Effects of the Catalonian Linguistic Normalization Policy One Generation after.” Journal of Sociolinguistics 12 (3): 306-33. doi:10.1111/j.14679841.2008.00369.x.

OECD. 2009. PISA 2009 Key Findings. Paris. http://www.oecd.org/pisa/pisaproducts/pisa2009keyfindings.htm.

Oxford, Rebecca L, and Jill Shearin. 1994. “Language Learning Motivation: Expanding the Theoretical Framework.” The Modern Language Journal 78 (1): 12-28. doi:10.2307/329249. 
Preacher, Kristopher J., and Andrew F. Hayes. 2007. “Contemporary Approaches to Assessing Mediation in Communication Research.” In The Sage Sourcebook of Advanced Data Analysis Methods for Communication Research, edited by Andrew F. Hayes, Michael D. Slater, and Leslie B. Snyder, 13-54. Thousand Oaks, CA: Sage Publications.

Pujolar, Joan. 2001. Gender, Heteroglossia and Power. A Sociolinguistic Study of Youth Culture. Berlin: Mouton de Gruyter.

Pujolar, Joan, and Isaac Gonzàlez. 2013. “Linguistic ' Mudes’ and the de-Ethnicization of Language Choice in Catalonia.” International Journal of Bilingual Education and Bilingualism 16 (2): 138-52. doi:10.1080/13670050.2012.720664.

Pujolar, Joan, and Maite Puigdevall. 2015. “Linguistic Mudes: How to Become a New Speaker in Catalonia.” International Journal of the Sociology of Language 231: 16787. doi:10.1515/ijsl-2014-0037.

Safont, Maria Pilar. 2007. "Language Use and Language Attitudes in the Valencian Community.” In Multilingualism in European Bilingual Contexts. Language Use and attitudes2, edited by David Lasagabaster and Ángel Huguet, 90-116. Clevedon, UK: Multilingual Matters.

Serra, Josep Maria. 1990. "Resultados Académicos y Dessarollo Cognitivo en un Programa de Inmersión Dirigido a Escolares de Nivel Sociocultural Bajo.” Infancia y Apredinzaje 47: 55-65.

Serrat, Elisabet, Lluïsa Gràcia, and Laia Perpiña. 2008. “First Language Influence on Second Language Acquisition: The Case of Immigrant L1 Soninke, Tagalog and Chinese Children Learning Catalan.” In A Portrait of the Young in the New Multilingual Spain, edited by Carmen Pérez Vidal and Maria Juan-Garau, 200-219. Clevedon, UK: Multilingual Matters.

Sharp, Derrick, Beryl Thomas, Eurwen Price, Gareth Francis, and Iwan Davies. 1973. Attitudes to Welsh and English in the Schools of Wales. London: Macmillan Education.

Siqués, Carina, Santiago Perera, and Ignasi Vila. 2012. "Variables Implicadas en la Adquisición del Catalán en las Aulas de Acogida de Educación Primaria de Cataluña. Un Estudio Empírico.” Anales de Psicologia 28 (2): 444-56.

Soler, Josep. 2012. “The Anonymity of Catalan and the Authenticity of Estonian: Two Paths for the Development of Medium-Sized Languages.” International Journal of 
Bilingual Education and Bilingualism 16 (2): 153-63.

doi:10.1080/13670050.2012.720665.

Strubell, Miquel. 2001. “Catalan a Decade Later.” In Can Threatened Languages Be Saved, edited by Joshua A. Fishman, 206-83. Clevedon: Multilingual Matters.

Trenchs-Parera, Mireia. 2013. “Les Vivències Sociolingüístiques I El Multilingüisme Dels Joves D’origen Xinès a Catalunya.” Revista de Didàctica de La Llengua I de La Literatura, no. 60: 28-39.

Trenchs-Parera, Mireia, Imanol Larrea Mendizabal, and Michael Newman. 2014. "La Normalització Del Cosmopolitisme Lingüístic Entre Els Joves Del Segle XXi? Una Exploració de Les Ideologies Lingüístiques a Catalunya.” Treballs de Sociolingüística Catalana 24: 281-301. doi:10.2436/20.2504.01.80.

Trenchs-Parera, Mireia, and Michael Newman. 2009. "Diversity of Language Ideologies in Spanish-Speaking Youth of Different Origins in Catalonia.” Journal of Multilingual and Multicultural Development 30 (6): 509-24. doi:10.1080/01434630903147914. . 2015. "Language Policies, Ideologies, and Attitudes, Part 2: International Immigration, Globalization and the Future of Catalan.” Linguistics and Language Compass 9 (12): 491-501. doi:10.1111/lnc3.12155.

Urla, Jacqueline. 2013. “Catalan in the Twenty-First Century.” International Journal of Bilingual Education and Bilingualism 16 (2): 177-81. doi:10.1080/13670050.2012.720667.

Vila, Ignasi. 1995. El Catalá i el Castellá en el Sistema Educatiu de Catalunya. Barcelona: ICE Horsori.

Wilson, Ann Elizabeth. 2012. "Interpreting Differences in Parental Encouragement to Learn the Host Language: California and Catalonia Compared.” Bellaterra Journal of Teaching \& Learning Language \& Literature 5 (3): 44-56.

Wood, Wendy. 2000. “Attitude Change: Persuasion and Social Influence.” Annual Review of Psychology 51: 539-70. doi:10.1146/annurev.psych.51.1.539.

Woolard, Kathryn A. 1991. "Linkages of Language and Ethnic Identity: Changes in Barcelona, 1980-1987.” In Language and Ethnicity: Focusschrift in Honor of Joshua A. Fishman on the Occasion of His 65th Birthday. Vol. 2, edited by James R. Dow, 61-81. Amsterdam/Philadelphia: John Benjamins Publ. Co.

—. 2008. "Language and Identity Choice in Catalonia: The Interplay of Contrasting Ideologies of Linguistic Authority.” In Lengua, Nacion E Identidad. La Regulacion 
Del Plurilinguismo En Espana Y America Latina, edited by Kirsten Suselbeck, Ulrike Muhlschelegel, and Masson Peter, 303-23. Madrid: Iberoamericana. . 2009. "Linguistic Consciousness among Adolescents in Catalonia: A Case Study from the Barcelona Urban Area in Longitudinal Perspective.” Perspective 22: 125-49. . 2012. "Is the Personal Political? Chronotopes and Changing Stances toward Catalan Language and Identity.” International Journal of Bilingual Education and Bilingualism 16 (2): 210-24. doi:10.1080/13670050.2012.720670.

Ytsma, J. 2007. “Language Use and Language Attitudes in Friesland.” In Multilingualism in European Bilingual Contexts. Language Use and attitudes2, edited by David Lasagabaster and Ángel Huguet, 144-63. Clevedon, UK: Multilingual Matters. 
Table 1. Autochthonous and immigrant students' distribution by home language and linguistic family

\begin{tabular}{|c|c|c|c|c|c|}
\hline \multicolumn{3}{|c|}{ Autochthonous students } & \multicolumn{3}{|c|}{ Immigrant students } \\
\hline Home language & $n$ & $\%$ & Linguistic family & $n$ & $\%$ \\
\hline Catalan & 281 & 42.2 & Sino-Tibetan & 18 & 3.7 \\
\hline Spanish & 248 & 37.2 & Indo- European & 343 & 70 \\
\hline \multirow[t]{4}{*}{ Catalan + Spanish } & 137 & 20.6 & Pacific & 1 & 0.2 \\
\hline & & & South American & 2 & 0.4 \\
\hline & & & Afro-Asiatic Filum & 94 & 19.2 \\
\hline & & & Nigerian Congolese Filum & 32 & 6.5 \\
\hline Total & 666 & 100 & Total & 490 & 100 \\
\hline
\end{tabular}


Table 2. Means and standard deviations of gender, socioeconomic status, sociocultural level, and Spanish/non-Spanish speaking as a function of origin.

\begin{tabular}{|c|c|c|c|c|c|c|c|c|c|c|c|c|}
\hline \multirow{3}{*}{ Variable } & \multicolumn{5}{|c|}{ Autochthonous } & \multicolumn{5}{|c|}{ Immigrant } & \multirow{3}{*}{ Interaction $F$} & \multirow{3}{*}{$p$} \\
\hline & \multirow[b]{2}{*}{$n$} & \multicolumn{2}{|c|}{ Attitudes toward Catalan } & \multicolumn{2}{|c|}{ Attitudes toward Spanish } & \multirow[b]{2}{*}{$n$} & \multicolumn{2}{|c|}{ Attitudes toward Catalan } & \multicolumn{2}{|c|}{ Attitudes toward Spanish } & & \\
\hline & & $M$ & $S D$ & $M$ & $S D$ & & $M$ & $S D$ & $M$ & $S D$ & & \\
\hline Origin & 666 & $\begin{array}{c}6.80 \\
{[6.48,7.11]}\end{array}$ & 4.13 & $\begin{array}{c}4.82 \\
{[4.44,5.17]}\end{array}$ & 5.05 & 490 & $\begin{array}{c}4.92 \\
{[4.51,5.39]}\end{array}$ & 4.75 & $\begin{array}{c}6.76 \\
{[6.37,6.96]}\end{array}$ & 3.05 & 84.15 & $<.001$ \\
\hline \multicolumn{13}{|l|}{ Gender } \\
\hline Boys & 347 & $\begin{array}{c}6.60 \\
{[6.12,7.04]}\end{array}$ & 4.27 & $\begin{array}{c}4.34 \\
{[3.77,4.89]}\end{array}$ & 5.34 & 239 & \multirow{2}{*}{$\begin{array}{c}4.43 \\
{[3.77,5.10]} \\
5.47 \\
{[4.95,5.96]}\end{array}$} & 5.03 & $\begin{array}{c}6.38 \\
{[5.96,6.80]}\end{array}$ & 3.53 & \multirow[t]{2}{*}{1.71} & \multirow[t]{2}{*}{.191} \\
\hline Girls & 319 & $\begin{array}{c}7.01 \\
{[6.60,7.44]}\end{array}$ & 3.97 & $\begin{array}{c}5.35 \\
{[4.83,5.86]}\end{array}$ & 4.67 & 251 & & 4.23 & $\begin{array}{c}6.95 \\
{[6.55,7.31]}\end{array}$ & 3.05 & & \\
\hline \multicolumn{13}{|l|}{ Socioeconomic status } \\
\hline Medium and high & 396 & $\begin{array}{c}7.14 \\
{[6.77,7.52]}\end{array}$ & 3.99 & $\begin{array}{c}4.03 \\
{[3.51,4.54]}\end{array}$ & 5.25 & 161 & \multirow{2}{*}{$\begin{array}{c}4.58 \\
{[3.81,5.41]} \\
5.15 \\
{[4.62,5.67]}\end{array}$} & 4.69 & $\begin{array}{c}6.62 \\
{[6.08,7.13]}\end{array}$ & 3.40 & \multirow[t]{2}{*}{14.80} & \multirow[t]{2}{*}{$<.001$} \\
\hline Low & 270 & $\begin{array}{c}6.29 \\
{[5.73,6.82]}\end{array}$ & 4.29 & $\begin{array}{c}5.98 \\
{[5.39,6.52]}\end{array}$ & 4.52 & 329 & & 4.64 & $\begin{array}{c}6.70 \\
{[6.36,7.01]}\end{array}$ & 3.04 & & \\
\hline \multicolumn{13}{|l|}{ Sociocultural level } \\
\hline University & 246 & $\begin{array}{c}7.56 \\
{[7.08,7.99]}\end{array}$ & 3.73 & $\begin{array}{c}3.57 \\
{[2.89,4.23]}\end{array}$ & 5.21 & 183 & \multirow{2}{*}{$\begin{array}{c}5.08 \\
{[4.37,5.73]} \\
4.90 \\
{[4.34,5.43]}\end{array}$} & 4.48 & $\begin{array}{c}6.99 \\
{[6.51,7.42]}\end{array}$ & 3.02 & \multirow[t]{2}{*}{17.39} & \multirow[t]{2}{*}{$<.001$} \\
\hline Secondary and primary & 420 & $\begin{array}{c}6.35 \\
{[5.92,6.76]}\end{array}$ & 4.29 & $\begin{array}{c}5.56 \\
{[5.06,6.02]}\end{array}$ & 4.81 & 307 & & 4.77 & $\begin{array}{c}6.49 \\
{[6.13,6.82]}\end{array}$ & 3.23 & & \\
\hline \multicolumn{13}{|c|}{ Spanish/ non-Spanish speaking } \\
\hline Spanish speakers & & & & & & 213 & $\begin{array}{c}3.85 \\
{[3.16,4.52]}\end{array}$ & 5.00 & $\begin{array}{c}7.53 \\
{[7.20,7.84]}\end{array}$ & 2.49 & \multirow[t]{2}{*}{46.84} & \multirow[t]{2}{*}{$<.001$} \\
\hline Non - Spanish speakers & & & & & & 277 & $\begin{array}{c}5.82 \\
{[5.33,6.28]}\end{array}$ & 4.20 & $\begin{array}{c}6.01 \\
{[5.63,6.39]}\end{array}$ & 3.46 & & \\
\hline
\end{tabular}

Note. 95\% BCa CIs based on 2000 bootstrap samples are reported in brackets. 
Table 3. Summary of results of the multiple regression analyses for the autochthonous group

\begin{tabular}{|c|c|c|c|c|c|c|}
\hline \multirow{2}{*}{ Variable } & \multicolumn{3}{|c|}{ Attitudes toward Catalan } & \multicolumn{3}{|c|}{ Attitudes toward Spanish } \\
\hline & $\boldsymbol{b}$ & $S E b$ & $\beta$ & $b$ & $S E b$ & $\boldsymbol{\beta}$ \\
\hline \multicolumn{7}{|l|}{ Step 1} \\
\hline Gender & $\begin{array}{c}0.44 \\
{[0.01,0.86]}\end{array}$ & 0.22 & $.05 *$ & $\begin{array}{c}0.49 \\
{[-0.03,1.05]}\end{array}$ & 0.27 & .05 \\
\hline SPS & $\begin{array}{c}0.82 \\
{[0.34,1.33]}\end{array}$ & 0.25 & $.10^{*}$ & $\begin{array}{c}-0.18 \\
{[-0.75,0.35]}\end{array}$ & 0.29 & -.02 \\
\hline SCS & $\begin{array}{c}-0.15 \\
{[-0.56,0.28]}\end{array}$ & 0.22 & -.02 & $\begin{array}{c}0.02 \\
{[-0.63,0.67]}\end{array}$ & 0.32 & .00 \\
\hline Catalan competences & $\begin{array}{c}-0.01 \\
{[-0.05,0.03]}\end{array}$ & 0.02 & -.02 & $\begin{array}{c}-0.01 \\
{[-0.05,0.03]}\end{array}$ & 0.02 & -.02 \\
\hline Spanish competences & $\begin{array}{c}0.01 \\
{[-0.02,0.04]}\end{array}$ & 0.02 & .03 & $\begin{array}{c}0.03 \\
{[-0.01,0.06]}\end{array}$ & 0.02 & .06 \\
\hline Self-ident. Catalonia & $\begin{array}{c}1.77 \\
{[1.36,2.16]}\end{array}$ & 0.21 & $.41^{*}$ & $\begin{array}{c}-0.40 \\
{[-0.78,-0.02]}\end{array}$ & 0.19 & -.08 \\
\hline Self-ident. Spain & $\begin{array}{c}-0.55 \\
{[-0.82,-0.29]}\end{array}$ & 0.13 & $-.15^{*}$ & $\begin{array}{c}2.32 \\
{[1.98,2.70]}\end{array}$ & 0.18 & $.51^{*}$ \\
\hline Use of Catalan & $\begin{array}{c}1.86 \\
{[1.32,2.41]}\end{array}$ & 0.26 & $.38 *$ & $\begin{array}{c}0.61 \\
{[0.13,1.11]}\end{array}$ & 0.25 & $.10^{*}$ \\
\hline Use of Spanish & $\begin{array}{c}0.47 \\
{[0.14,0.77]} \\
\end{array}$ & 0.16 & $.10^{*}$ & $\begin{array}{c}1.88 \\
{[1.41,2.34]}\end{array}$ & 0.25 & $.32 *$ \\
\hline $\mathbf{R}^{2}$ & & $.58^{*}$ & & & $.57 *$ & \\
\hline $\mathbf{F}$ & & 101.29 & & & 94.68 & \\
\hline
\end{tabular}

Note. SPS = socioeconomic status; SCL = sociocultural level.

$* p<.05$. 
Table 4. Summary of results of the multiple regression analyses for the immigrant group

\begin{tabular}{|c|c|c|c|c|c|c|}
\hline \multirow{2}{*}{ Variable } & \multicolumn{3}{|c|}{ Attitudes toward Catalan } & \multicolumn{3}{|c|}{ Attitudes toward Spanish } \\
\hline & $b$ & $S E b$ & $\beta$ & $b$ & $S E b$ & $\beta$ \\
\hline \multicolumn{7}{|l|}{ Step 1} \\
\hline Gender & $\begin{array}{c}1.24 \\
{[0.45,2.03]}\end{array}$ & 0.38 & $.13^{*}$ & $\begin{array}{c}0.47 \\
{[-0.03,0.95]}\end{array}$ & 0.25 & .08 \\
\hline SPS & $\begin{array}{c}0.83 \\
{[-0.07,1.76]}\end{array}$ & 0.46 & .08 & $\begin{array}{c}0.25 \\
{[-0.29,0.83]}\end{array}$ & 0.28 & .04 \\
\hline Cralan comnetences & $\begin{array}{c}-0.84 \\
{[-1.70,-0.03]} \\
0.02\end{array}$ & 0.43 & $-.09 *$ & $\begin{array}{c}-0.32 \\
{[-0.86,0.22]} \\
0.03\end{array}$ & 0.26 & -.05 \\
\hline Catalan competences & $\begin{array}{c}{[-0.01,0.05]} \\
0.002\end{array}$ & 0.02 & .07 & $\begin{array}{c}{[0.01,0.05]} \\
-0.01\end{array}$ & 0.01 & $.20^{*}$ \\
\hline Spanish competences & $\begin{array}{c}{[-0.03,0.03]} \\
1.05\end{array}$ & 0.02 & .01 & $\begin{array}{c}{[-0.03,0.02]} \\
-0.20\end{array}$ & 0.01 & -.04 \\
\hline Self-id. Spain & $\begin{array}{c}{[0.56,1.56]} \\
0.06\end{array}$ & 0.25 & $.23^{*}$ & $\begin{array}{c}{[0.57,0.16]} \\
0.36\end{array}$ & 0.19 & -.07 \\
\hline Use of Catalan & $\begin{array}{c}{[-0.37,0.49]} \\
1.41\end{array}$ & 0.22 & $25 *$ & $\begin{array}{c}{[0.04,0.67]} \\
-0.18\end{array}$ & 0.17 & $.13 *$ \\
\hline Use of Spanish & $\begin{array}{c}{[0.88,1.96]} \\
-0.69 \\
{[-1.24,-0.08]}\end{array}$ & 0.28 & $-.11^{*}$ & $\begin{array}{c}{[-0.55,0.20]} \\
1.27 \\
{[0.80,1.75]}\end{array}$ & 0.25 & -.05 \\
\hline$R^{2}$ & & $.26 *$ & & & $.17^{*}$ & \\
\hline $\boldsymbol{F}$ & & 18.53 & & & 11.26 & \\
\hline \multicolumn{7}{|l|}{ Step 2} \\
\hline Gender & $\begin{array}{c}1.23 \\
{[0.41,2.05]}\end{array}$ & 0.39 & $.13^{*}$ & $\begin{array}{c}0.49 \\
{[-0.01,0.96]}\end{array}$ & 0.25 & .08 \\
\hline SPS & $\begin{array}{c}0.81 \\
{[-0.09,1.74]}\end{array}$ & 0.46 & .08 & $\begin{array}{c}0.24 \\
{[-0.31,0.82]}\end{array}$ & 0.28 & .04 \\
\hline SCS & $\begin{array}{c}-0.78 \\
{[-1.63,0.05]}\end{array}$ & 0.44 & -.08 & $\begin{array}{c}-0.23 \\
{[-0.77,0.32]}\end{array}$ & 0.27 & -.04 \\
\hline Catalan competences & $\begin{array}{c}0.02 \\
{[-0.01,0.06]}\end{array}$ & 0.02 & .10 & $\begin{array}{c}0.04 \\
{[0.02,0.06]}\end{array}$ & 0.01 & $.26^{*}$ \\
\hline Spanish competences & $\begin{array}{c}0.001 \\
{[-0.03,0.03]}\end{array}$ & 0.02 & .003 & $\begin{array}{c}-0.01 \\
{[-0.03,0.01]}\end{array}$ & 0.01 & -.09 \\
\hline Self-ident. Catalonia & $\begin{array}{c}1.08 \\
{[0.59,1.60]}\end{array}$ & 0.26 & $.24^{*}$ & $\begin{array}{c}{[-0.20} \\
{[-0.57,0.16]}\end{array}$ & 0.19 & -.07 \\
\hline Self-ident. Spain & $\begin{array}{c}0.07 \\
{[-0.36,0.51]}\end{array}$ & 0.22 & .02 & $\begin{array}{c}0.42 \\
{[0.10,0.73]}\end{array}$ & 0.17 & $.15^{*}$ \\
\hline Use of Catalan & $\begin{array}{c}1.47 \\
{[0.94,2.03]}\end{array}$ & 0.28 & $.27^{*}$ & $\begin{array}{c}-0.01 \\
{[-0.46,0.31]}\end{array}$ & 0.20 & -.03 \\
\hline Use of Spanish & $\begin{array}{c}-0.70 \\
{[-1.29,-0.04]}\end{array}$ & 0.30 & $-.11^{*}$ & $\begin{array}{c}1.13 \\
{[0.62,1.65]}\end{array}$ & 0.27 & $.28^{*}$ \\
\hline Spanish-speaking & $\begin{array}{c}-0.13 \\
{[-1.16,0.87]}\end{array}$ & 0.52 & -.01 & $\begin{array}{c}-0.66 \\
{[-1.34,-0.01]}\end{array}$ & 0.35 & $-.11^{*}$ \\
\hline LoR & $\begin{array}{c}-0.06 \\
{[-0.18,0.05]}\end{array}$ & 0.06 & -.06 & $\begin{array}{c}-0.04 \\
{[-0.11,0.03]}\end{array}$ & 0.04 & -.06 \\
\hline$\Delta R^{2}$ & & .003 & & & $.01 *$ & \\
\hline F change & & 0.88 & & & 3.10 & \\
\hline
\end{tabular}

Note . SPS = socioeconomic status; SCL = sociocultural level; LoR = length of residence. $* p<.05$. 